\title{
Calcium dynamics in vascular smooth muscle
}

\author{
Gregory C. Amberg ${ }^{1}$ and Manuel F. Navedo ${ }^{2}$ \\ ${ }^{1}$ Vascular Physiology Research Group, Department of Biomedical Sciences, Colorado State \\ University, Fort Collins, CO 80523 \\ ${ }^{2}$ Department of Pharmacology, University of California, Davis, Davis, CA 95616
}

\begin{abstract}
Smooth muscle cells are ultimately responsible for determining vascular luminal diameter and blood flow. Dynamic changes in intracellular calcium are a critical mechanism regulating vascular smooth muscle contractility. Processes influencing intracellular calcium are therefore important regulators of vascular function with physiological and pathophysiological consequences. In this review we discuss the major dynamic calcium signals identified and characterized in vascular smooth muscle cells. These signals vary with respect to their mechanisms of generation, temporal properties, and spatial distributions. The calcium signals discussed include calcium waves, junctional calcium transients, calcium sparks, calcium puffs, and L-type calcium channel sparklets. For each calcium signal we address underlying mechanisms, general properties, physiological importance, and regulation.
\end{abstract}

\section{Introduction}

The otherwise unassuming inorganic divalent cation calcium $\left(\mathrm{Ca}^{2+}\right)$ is the most important signaling molecule in mammalian cells. Cellular responses to changes in intracellular $\mathrm{Ca}^{2+}$ $\left(\left[\mathrm{Ca}^{2+}\right]_{\mathrm{i}}\right)$ often underlie our definition of what a given cell "is" (22). For example, following an increase in $\left[\mathrm{Ca}^{2+}\right]_{i}$, endocrine cells secrete hormones and neurons release neurotransmitters. Muscle cells, including vascular smooth muscle cells, generally contract when $\left[\mathrm{Ca}^{2+}\right]_{\mathrm{i}}$ rises. $\mathrm{Ca}^{2+}$ induces contraction in these cells by complexing with the ubiquitous $\mathrm{Ca}^{2+}$ binding protein calmodulin and subsequently increasing the activity of myosin light-chain kinase (MLCK; see Figure 1). Changes in the contractile state of vascular smooth muscle either increases or decreases vascular diameter, which in turn increases or decreases blood flow through the vessel and subsequently the vascularized tissue. Thus, events which influence $\left[\mathrm{Ca}^{2+}\right]_{i}$ are critical regulators of vascular function with clear physiological (and pathophysiological) ramifications.

Due to the importance of $\mathrm{Ca}^{2+}$, it is not unexpected that changes in vascular smooth muscle $\left[\mathrm{Ca}^{2+}\right]_{\mathrm{i}}$ (i.e., " $\mathrm{Ca}^{2+}$ dynamics") are governed by a complex array of cellular processes. Indeed, to arrive at the appropriate physiological response, vascular smooth muscle cells must integrate multiple signaling events that influence $\left[\mathrm{Ca}^{2+}\right]_{\mathrm{i}}$ either directly or indirectly (see Figure 1). In this paper we provide an overview of the major $\mathrm{Ca}^{2+}$ signals that contribute to changes in vascular smooth muscle $\left[\mathrm{Ca}^{2+}\right]_{\mathrm{i}}$. Note that many excellent and more extensive reviews on the individual topics discussed here are readily found in the published literature.

Corresponding Author: Gregory C. Amberg, PharmD., Ph.D., Colorado State University, Department of Biomedical Sciences, 1617 Campus Delivery. Fort Collins, CO 80523-1617, Phone: 970-491-6028, Fax: 970-491-7907, Gregory.Amberg@ colostate.edu. 


\section{Calcium signals in vascular smooth muscle}

Sources of $\mathrm{Ca}^{2+}$ available for cytoplasmic signaling in vascular smooth muscle cells include $\mathrm{Ca}^{2+}$ influx through ion-permeable channels located in the plasma membrane and $\mathrm{Ca}^{2+}$ release from intracellular $\mathrm{Ca}^{2+}$ stores (e.g., the sarcoplasmic reticulum). $\mathrm{Ca}^{2+}$ influx in vascular smooth muscle is mediated primarily by voltage-dependent $\mathrm{L}$-type $\mathrm{Ca}^{2+}$ channels (39) with contributions from other channels including but not limited to voltage-dependent T-type $\mathrm{Ca}^{2+}$ channels, $\mathrm{Ca}^{2+}$-permeable members of the transient receptor potential (TRP) superfamily of cation channels, and $\mathrm{Ca}^{2+}$-permeable ligand-gated cation channels. $\mathrm{Ca}^{2+}$ release from intracellular stores is mediated by two types of $\mathrm{Ca}^{2+}$-permeable ion channels located in sarcoplasmic reticular membranes: 1) Ryanodine receptors and 2) inositol 1,4,5trisphosphate $\left(\mathrm{IP}_{3}\right)$ receptors.

Cytoplasmic signals produced by these $\mathrm{Ca}^{2+}$ fluxes can be loosely classified as either more or less localized with respect to total cell volume (see Figure 2). Here we have grouped the "less than global" subcellular $\mathrm{Ca}^{2+}$ signals observed in vascular smooth muscle into five categories: 1) $\mathrm{Ca}^{2+}$ waves, 2) junctional $\mathrm{Ca}^{2+}$ transients, 3) $\mathrm{Ca}^{2+}$ sparks, 4) $\mathrm{Ca}^{2+}$ puffs, and 5) L-type $\mathrm{Ca}^{2+}$ channel sparklets. Note that $\mathrm{IP}_{3}$-receptor-mediated $\mathrm{Ca}^{2+}$ puffs have not been definitively isolated and visualized in vascular smooth muscle cells to the best of our knowledge. This non-arbitrary categorization of subcellular $\mathrm{Ca}^{2+}$ signaling events is based on a wealth of experimental evidence obtained by numerous research groups over the past few decades. The general biophysical characteristics (when known) of each of these subcellular $\mathrm{Ca}^{2+}$ signals is presented in Table 1 .

In contrast to increased global $\left[\mathrm{Ca}^{2+}\right]_{\mathrm{i}}$, which is invariably associated with contraction (29), the role of specific subcellular $\mathrm{Ca}^{2+}$ signals is not always apparent. For instance, while $\mathrm{Ca}^{2+}$ events such as junctional $\mathrm{Ca}^{2+}$ transients are inherently contractile $(32,63,65), \mathrm{Ca}^{2+}$ microdomains such as $\mathrm{Ca}^{2+}$ sparks may induce vasodilation (see below; (46)). This highlights the complexity of $\mathrm{Ca}^{2+}$ dynamics in vascular smooth muscle and the need for further investigation of subcellular $\mathrm{Ca}^{2+}$ signaling in these cells.

\section{Calcium waves}

As suggested by the moniker, $\mathrm{Ca}^{2+}$ waves are propagating $\left[\mathrm{Ca}^{2+}\right]_{\mathrm{i}}$ elevations produced by sequential series of $\mathrm{Ca}^{2+}$ release events from the sarcoplasmic reticulum that extend from one end of the cell to the other $(23,38,66) . \mathrm{Ca}^{2+}$ waves have been shown to be produced by $\mathrm{Ca}^{2+}$ release via $\mathrm{IP}_{3}$ and ryanodine receptors located in the sarcoplasmic reticulum $(20,26)$. By their nature $\mathrm{Ca}^{2+}$ waves inherently require a regenerative $\mathrm{Ca}^{2+}$ release mechanism that promotes propagation of the wavefront. This is thought to occur by a $\mathrm{Ca}^{2+}$-induced $\mathrm{Ca}^{2+}$ release (CICR) mechanism between adjacent $\mathrm{IP}_{3}$ and/or ryanodine receptors $(7,9,25,26)$. A schematic representation of an $\mathrm{IP}_{3}$ receptor-dependent $\mathrm{Ca}^{2+}$ wave is shown in Figure 3. In this scenario, the $\mathrm{Ca}^{2+}$ wave is initiated by localized $\mathrm{SR} \mathrm{Ca}^{2+}$ release via $\mathrm{IP}_{3}$-dependent opening of $\mathrm{IP}_{3}$ receptors. A self-perpetuating $\mathrm{Ca}^{2+}$ wave arises when the initiating $\mathrm{Ca}^{2+}$ induces $\mathrm{Ca}^{2+}$-dependent opening of adjacent $\mathrm{IP}_{3}$ receptors (i.e., $\mathrm{Ca}^{2+}$-induced $\mathrm{Ca}^{2+}$-release). $\mathrm{Ca}^{2+}$ release via ryanodine receptors has also been implicated in $\mathrm{Ca}^{2+}$ wave generation via frequent discharge sites in rat and rabbit portal vein $(7,20,64)$. In addition, application of the alkaloid ryanodine eliminated $\mathrm{Ca}^{2+}$ waves in pressurized rat cerebral arteries $(25,62)$. This suggests that in some arterial smooth muscle cells $\mathrm{Ca}^{2+}$ waves involve $\mathrm{SR} \mathrm{Ca}^{2+}$ release via ryanodine receptors.

The occurrence of $\mathrm{Ca}^{2+}$ waves in excised vessel preparations is variable to moderate under resting conditions. For example, smooth muscle cells in mouse cremaster feed arteries (62) and rat retinal arterioles exhibit moderate basal $\mathrm{Ca}^{2+}$ wave activity (56) while mouse and rat mesenteric arterial smooth muscle cells often possess minimal $\mathrm{Ca}^{2+}$ wave activity in the 
absence of stimulation $(38,65)$. The occurrence of basal $\mathrm{Ca}^{2+}$ waves appears to be dependent on phospholipase C (PLC) activity (62). Consistent with a role of PLC in regulating $\mathrm{Ca}^{2+}$ waves, increased production of $\mathrm{IP}_{3}$ by PLC following stimulation of $\mathrm{a}_{1}$ adrenergic receptors by norepinephrine in mesenteric arteries (31) and $\mathrm{ET}_{\mathrm{A}}$ receptors by endothelin-1 in retinal arterioles (56) increases $\mathrm{Ca}^{2+}$ wave frequency.

$\mathrm{Ca}^{2+}$ waves are postulated to contract vascular smooth muscle by at least two distinct mechanisms (21). $\mathrm{Ca}^{2+}$ released into the cytosol during the wave event can contribute to global $\mathrm{Ca}^{2+}$ thus increasing MLCK activity and promoting contraction (33). This is perhaps the most common interpretation of $\mathrm{Ca}^{2+}$ wave function. However, in contrast to this direct mechanism, $\mathrm{Ca}^{2+}$ waves can also influence contraction indirectly by interacting with and changing the activity of plasmalemmal $\mathrm{Ca}^{2+}$-activated ion channels. $\mathrm{Ca}^{2+}$ waves in rat retinal arteriole smooth muscle cells elicit $\mathrm{Ca}^{2+}$-activated chloride $\left(\mathrm{Cl}_{\mathrm{Ca}}\right)$ currents (56). Stimulation of $\mathrm{Ca}^{2+}$-activated chloride channels results in a depolarization of the plasma membrane via $\mathrm{Cl}^{-}$efflux (an inward current by convention; see Figure 3), thus enhancing voltage-dependent $\mathrm{L}$-type $\mathrm{Ca}^{2+}$ channel activity, and consequently, $\mathrm{Ca}^{2+}$ influx, global $\left[\mathrm{Ca}^{2+}\right]_{i}$, and ultimately contraction.

As noted above, $\mathrm{Ca}^{2+}$ waves are associated with increased vascular smooth muscle contraction in excised vessels. For example, in rat mesenteric arteries, asynchronous $\mathrm{Ca}^{2+}$ waves (with respect to adjacent smooth muscle cells) following neurogenic activation of $a_{1}$ receptors by norepinephrine contribute to gradually-developing contractions (31). Contractile responses to bath applied a 1 agonists (e.g., phenylephrine) also include a rapid initial component due to synchronous $\mathrm{Ca}^{2+}$ wave activity. This is likely an experimental artifact resulting from strong uniform (i.e., non-physiological) activation of a 1 receptors on a large population of smooth muscle cells $(31,67)$. Despite a substantial body of experimental data, the physiological significance of $\mathrm{Ca}^{2+}$ waves is poorly understood. For example, $\mathrm{Ca}^{2+}$ waves in mouse mesenteric arteries appear to cease following the development of tone (65) and evidence suggests that $\mathrm{Ca}^{2+}$ waves, which are readily observed in numerous excised vessels (as described above), are not apparent in corresponding in vivo experiments (36). Thus, much work is required to understand the physiological role of $\mathrm{Ca}^{2+}$ waves in the vasculature.

\section{Junctional Calcium Transients}

Short-lived $\mathrm{Ca}^{2+}$ influx events evoked by neural (i.e., sympathetic) stimulation of vascular smooth muscle cells are defined as junctional $\mathrm{Ca}^{2+}$ transients $(34,63)$. In contrast to $\mathrm{Ca}^{2+}$ waves, junctional $\mathrm{Ca}^{2+}$ transients remain localized, as they do not possess a regenerating or propagating mechanism. Action potentials arriving at perivascular sympathetic nerve terminals culminate in release of neurotransmitters, including ATP and norepinephrine. ATP activates postjunctional vascular smooth muscle $\mathrm{P} 2 \mathrm{X}_{1}$ purinergic receptors and norepinephrine stimulates $\mathrm{a}_{1}$ adrenergic receptors giving rise to $\mathrm{Ca}^{2+}$ waves as described above $(31,32,35)$ (see Figure 4).

$\mathrm{P} 2 \mathrm{X}_{1}$ receptors are ligand-gated $\mathrm{Ca}^{2+}$-permeable nonselective cation channels (16). In vascular beds innervated by the sympathetic nervous system (e.g., mesenteric arteries), stimulation of vascular smooth muscle $\mathrm{P} 2 \mathrm{X}_{1}$ receptors by ATP generates localized junctional $\mathrm{Ca}^{2+}$ transients on account of the relatively high $\mathrm{Ca}^{2+}$ permeability of these channels $(32,34)$. Temporally mirroring the kinetics of the junctional $\mathrm{Ca}^{2+}$ transients, the $\mathrm{Ca}^{2+}$ influx associated with these events induces a rapid but brief increase in contraction $(31,32)$. Non-neuronal stimulation of $\mathrm{P} 2 \mathrm{X}_{1}$ receptors has also been described. In mouse renal afferent arterioles, increasing intraluminal pressure promotes local release of ATP, 
stimulation of smooth muscle $\mathrm{P} 2 \mathrm{X}_{1}$ receptors, and contraction (24). This paracrine signaling mechanism is thought to contribute to autoregulation of blood flow in the kidney.

In addition to evoking local junctional $\mathrm{Ca}^{2+}$ transients, activation of $\mathrm{P} 2 \mathrm{X}_{1}$ receptors by ATP induces depolarizing excitatory junctional potentials as a result of $\mathrm{Na}^{+}$and (to a lesser extent) $\mathrm{Ca}^{2+}$ influx $(16,67)$. Depolarization increases the opening of $\mathrm{L}$-type $\mathrm{Ca}^{2+}$ channels resulting in increased $\mathrm{Ca}^{2+}$ influx and elevated global $\left[\mathrm{Ca}^{2+}\right]_{\mathrm{i}}$. Thus, stimulation of $\mathrm{P} 2 \mathrm{X}_{1}$ receptors with ATP increases vascular smooth muscle $\mathrm{Ca}^{2+}$ influx by two independent mechanisms: 1) Local junctional $\mathrm{Ca}^{2+}$ transients via $\mathrm{Ca}^{2+}$ entry through the $\mathrm{P} 2 \mathrm{X}_{1}$ receptors and 2) non-localized $\mathrm{Ca}^{2+}$ influx through $\mathrm{L}$-type $\mathrm{Ca}^{2+}$ channels following depolarizing excitatory junction potentials. These two complimentary $\mathrm{Ca}^{2+}$ influx mechanisms summate to underlie the initial component of sympathetic-mediated contraction of rat mesenteric arteries (67).

\section{Calcium Sparks}

$\mathrm{Ca}^{2+}$ sparks are localized $\mathrm{Ca}^{2+}$ microdomains produced specifically by the opening of the ryanodine receptor class of intracellular $\mathrm{Ca}^{2+}$ release channels located in sarcoplasmic reticular membranes (12). In vascular smooth muscle $\mathrm{Ca}^{2+}$ sparks have minimal direct impact on global $\left[\mathrm{Ca}^{2+}\right]_{\mathrm{i}}$ and contraction as a consequence of their limited spatial spread (46). However, $\mathrm{Ca}^{2+}$ sparks can have substantial influence on global $\left[\mathrm{Ca}^{2+}\right]_{\mathrm{i}}$ and contraction through indirect mechanisms. Accordingly, regions of sarcoplasmic reticulum are often found in close juxtaposition to the plasma membrane of vascular smooth muscle cells $(\approx 10$ $20 \mathrm{~nm} ;(14,28,57))$. As noted above, $\mathrm{Ca}^{2+}$-activated plasmalemmal ion channels (e.g., $\mathrm{K}_{\mathrm{Ca}}$ and $\mathrm{Cl}_{\mathrm{Ca}}$ ) are expressed in various vascular smooth muscle cells. $\mathrm{Ca}^{2+}$ sparks occurring in close proximity to these channels can increase local $\left[\mathrm{Ca}^{2+}\right]_{\mathrm{i}}$ to levels sufficient (i.e., $\mu \mathrm{M}$; (48)) for channel activation (see Figure 5). Thus, the contractile response of vascular smooth muscle to $\mathrm{Ca}^{2+}$ sparks depends on the expression and coupling of the sparks to $\mathrm{Ca}^{2+}$ activated plasmalemmal ion channels.

In rat and mouse cerebral arteries, large-conductance, $\mathrm{Ca}^{2+}$-activated $\mathrm{K}^{+}(\mathrm{BK}$; maxi $\mathrm{K})$ channels are a primary $\mathrm{K}_{\mathrm{Ca}}$ target for $\mathrm{Ca}^{2+}$ sparks $(27,46) . \mathrm{Ca}^{2+}$ spark activation of $\mathrm{BK}$ channels results in a stereotypical temporal pattern of hyperpolarizing $\mathrm{K}^{+}$currents called spontaneous transient outward currents (STOCs) $(6,46)$. Simultaneous recording of intracellular $\mathrm{Ca}^{2+}$ and membrane potential has provided definitive evidence that $\mathrm{Ca}^{2+}$ sparks give rise to STOCs as the two events correlate not only in time but also in magnitude $(1,10$, $46,48)$. In rat cerebral arteries elimination of $\mathrm{Ca}^{2+}$ sparks eliminates contractile responses to BK channel inhibition $(30,46)$ thus indicating that $\mathrm{Ca}^{2+}$ sparks are the physiological activators of BK channels in these vascular smooth muscle cells.

In rabbit portal vein, $\mathrm{Ca}^{2+}$ sparks are coupled to $\mathrm{Cl}_{\mathrm{Ca}}$ channels (59). In contrast to $\mathrm{Ca}^{2+}$ spark activation of $\mathrm{BK}$ channels, which results in hyperpolarization, $\mathrm{Ca}^{2+}$ spark activation of $\mathrm{Ca}^{2+}$-activated $\mathrm{Cl}^{-}$channels causes plasma membrane depolarizing outward currents (via $\mathrm{Cl}^{-}$efflux; see Figure 5). Consequently, similar to $\mathrm{Ca}^{2+}$-activated $\mathrm{K}^{+}$channels, activation of $\mathrm{Ca}^{2+}$-activated $\mathrm{Cl}^{-}$channels by $\mathrm{Ca}^{2+}$ sparks produces a signature pattern of inward current called spontaneous transient inward currents (STICs) that correlate in time and magnitude with each other. Depolarization induced by $\mathrm{Ca}^{2+}$-activated $\mathrm{Cl}^{-}$channel activity results in activation of voltage dependent L-type $\mathrm{Ca}^{2+}$ channels and increased contraction (see Figure 5) (51).

The dependence of $\mathrm{Ca}^{2+}$-activated ion channels on underlying $\mathrm{Ca}^{2+}$ sparks provides an opportunity for regulation of vascular smooth muscle function by vasodilators and vasoconstrictors. In rat cerebral arteries, vasodilators increase the hyperpolarizing influence of BK channels by increasing the sensitivity of the BK channels to $\mathrm{Ca}^{2+}$ and by increasing 
$\mathrm{Ca}^{2+}$ spark (thus STOC) frequency $(49,54)$. These effects are mediated by activation of adenosine $3^{\prime}, 5^{\prime}$-cyclic monophosphate (cAMP)/protein kinase A (PKA) and guanosine $3^{\prime}$, $5^{\prime}$-cyclic monophosphate (cGMP)/protein kinase G (PKG) signaling cascades. Thus, vasodilators can increase BK channel activity by increasing the coupling strength between the channel and the $\mathrm{Ca}^{2+}$ sparks (increasing STOC amplitude) and increasing the occurrence of $\mathrm{Ca}^{2+}$ sparks (increasing STOC frequency). Conversely, vasoconstrictors associated with protein kinase $\mathrm{C}$ (PKC) decrease the hyperpolarizing influence of $\mathrm{BK}$ channels by decreasing $\mathrm{BK}$ channel sensitivity to $\mathrm{Ca}^{2+}$ (reducing STOC amplitude) and by reducing the occurrence of $\mathrm{Ca}^{2+}$ sparks (reducing STOC frequency) $(8,54)$.

The coupling strength between $\mathrm{Ca}^{2+}$ sparks and $\mathrm{BK}$ channels is also associated with vascular dysfunction during diseases such as hypertension. The sensitivity of vascular smooth muscle BK channels to $\mathrm{Ca}^{2+}$ is greatly dependent on expression of $\mathrm{BK}$ channel $\beta 1$ subunits (10). Genetic ablation of the $\beta 1$ subunit decreases the sensitivity of cerebral arterial smooth muscle $\mathrm{BK}$ channels to $\mathrm{Ca}^{2+}$. As a consequence, $\mathrm{Ca}^{2+}$ sparks in these cells do not efficiently generate corresponding STOCs (10). This results in increased contraction of excised cerebral arterial segments and increased mean arterial blood pressure. Similarly, in rat models of hypertension, the function and expression of BK channel $\beta 1$ subunits in cerebral arteries is decreased and contributes to vascular dysfunction $(1,4)$.

\section{Calcium Puffs}

$\mathrm{Ca}^{2+}$ puffs are localized $\mathrm{Ca}^{2+}$ microdomains produced by the opening of sarcoplasmic reticulum $\mathrm{IP}_{3}$ receptors (58). Although $\mathrm{Ca}^{2+}$ puffs have been observed in colonic smooth muscle cells (5), they have not been visualized in vascular smooth muscle cells. However, indirect experimental evidence in rat cerebral arterial smooth muscle cells indicates that physiologically-relevant localized IP3 receptor-dependent $\mathrm{Ca}^{2+}$ release does occur $(17,18)$. Indeed, in these smooth muscle cells, IP3-dependent $\mathrm{Ca}^{2+}$ release has been shown to promote the opening of transient receptor potential melastatin 4 (TRPM4) channels. Opening of these $\mathrm{Ca}^{2+}$-activated, $\mathrm{Na}^{+}$-permeable cation channels causes arterial smooth muscle membrane depolarization, opening of voltage-dependent L-type $\mathrm{Ca}^{2+}$ channels, $\mathrm{Ca}^{2+}$ influx, and ultimately contraction (see Figure 6) (17-19). A more detailed explanation of these findings can be found in the accompany paper by Gonzales and Earley in this special issue of Microcirculation.

\section{Calcium Sparklets}

$\mathrm{Ca}^{2+}$ sparklets are distinct $\mathrm{Ca}^{2+}$ microdomains produced by plasmalemmal $\mathrm{Ca}^{2+}$-permeable channels. Despite the name, $\mathrm{Ca}^{2+}$ sparklets are not small $\mathrm{Ca}^{2+}$ sparks. $\mathrm{Ca}^{2+}$ sparklets arise from $\mathrm{Ca}^{2+}$ influx through plasmalemmal ion channels (see below) and (as discussed above) $\mathrm{Ca}^{2+}$ sparks arise from the release of $\mathrm{Ca}^{2+}$ from the sarcoplasmic reticulum through ryanodine receptors (see Figure 7).

The original definition of a " $\mathrm{Ca}^{2+}$ sparklet" was a visualized $\mathrm{Ca}^{2+}$ influx event produced by a voltage-dependent $\mathrm{L}$-type $\mathrm{Ca}^{2+}$ channel (60). Since that time, $\mathrm{Ca}^{2+}$ influx events produced by other $\mathrm{Ca}^{2+}$-permeable channels have been visualized and referred to as " $\mathrm{Ca}^{2+}$ sparklets" (e.g., (55). To remove ambiguity we suggest that that the term " $\mathrm{Ca}^{2+}$ sparklet" be refined to specifically designate the visualization of a $\mathrm{Ca}^{2+}$ influx event through a $\mathrm{Ca}^{2+}$-permeable plasmalemmal ion channel. The need for different terms denoting $\mathrm{Ca}^{2+}$ influx through different channels can then be eliminated by preceding "sparklets" with the name of the underlying channel (e.g., "L-type $\mathrm{Ca}^{2+}$ channel sparklets", "TRPV4 sparklets", etc...). 


\section{L-Type Calcium Channel Sparklets}

Cav1.2 L-type $\mathrm{Ca}^{2+}$ channels are the main source of $\mathrm{Ca}^{2+}$ influx in vascular smooth muscle cells (39). Conventional electrophysiological recordings of steady-state $\mathrm{L}$-type $\mathrm{Ca}^{2+}$ channel activity (50) provide no information with regard to potential spatial heterogeneity of L-type $\mathrm{Ca}^{2+}$ channel activity throughout the smooth muscle plasma membrane. However, when conventional electrophysiology and advanced $\mathrm{Ca}^{2+}$ imaging techniques (e.g., total internal reflection fluorescence (TIRF) microscopy) are used together this experimental limitation is overcome $(41,60)$.

Using a combinatorial approach of electrophysiology and TIRF microscopy, $\mathrm{Ca}^{2+}$ influx through single L-type $\mathrm{Ca}^{2+}$ channels (i.e., L-type $\mathrm{Ca}^{2+}$ channel sparklets) is readily observed in smooth muscle cells isolated from rat and mouse cerebral and mesenteric arteries $(2,3$, 40-42). Data from experiments using this approach have confirmed the importance of Cav1.2 channels in vascular smooth muscle and yielded unexpected information with regard to spatial organization and regulation of L-type $\mathrm{Ca}^{2+}$ channels $(40,41)$ ). Previous conventional electrophysiological data suggested that, under steady-state conditions, $\mathrm{Ca}^{2+}$ influx in vascular smooth muscle cells was the end result of stochastic opening of L-type $\mathrm{Ca}^{2+}$ channels dispersed broadly throughout the plasma membrane (50). However, the exceptional temporal and spatial resolution provided by TIRF microscopy revealed that $\mathrm{Ca}^{2+}$ influx in vascular smooth muscle cells through L-type $\mathrm{Ca}^{2+}$ channels is not stochastic but rather segregates strikingly into sites of low and high activity (see Figure 7).

Consistent with conventional electrophysiological data, sites of low activity L-type $\mathrm{Ca}^{2+}$ channel influx arise from stochastic opening of randomly dispersed L-type $\mathrm{Ca}^{2+}$ channels. In contrast, sites of high activity L-type $\mathrm{Ca}^{2+}$ channel function result from non-stochastic, apparently coordinated opening of clustered channels $(15,43)$. High activity L-type $\mathrm{Ca}^{2+}$ channel sparklet sites require AKAP150-targeted kinase activity (i.e., PKC and PKA), account for approximately $50 \%$ of the steady-state $\mathrm{Ca}^{2+}$ entry through L-type $\mathrm{Ca}^{2+}$ channels in isolated rat and mouse cerebral arterial smooth muscle cells. In addition, High activity Ltype $\mathrm{Ca}^{2+}$ channel sparklets contribute to myogenic tone in mouse mesenteric arteries and are necessary for contractile responses of mouse mesenteric and rat cerebral arteries to angiotensin II $(3,11,44,45,47)$. Microdomains of elevated $\mathrm{Ca}^{2+}$ generated by high-activity L-type $\mathrm{Ca}^{2+}$ channel sparklet sites also induce changes in gene expression via specific activation of the $\mathrm{Ca}^{2+} /$ calcineurin/NFAT signaling pathway $(47,52,53)$. A more detailed explanation of these concepts can be found in the accompany paper by Navedo and Amberg in this special issue of Microcirculation.

\section{Other Considerations and Future Directions}

The $\mathrm{Ca}^{2+}$ signals described above are defined by the molecular mechanisms underlying their initiation and are classified as different "less than global" $\mathrm{Ca}^{2+}$ events with unique properties. While mechanisms underlying $\mathrm{Ca}^{2+}$ entry into vascular smooth muscle cytosol clearly distinguish one $\mathrm{Ca}^{2+}$ signal from another, termination of these events is also critical. $\mathrm{Ca}^{2+}$ signals in vascular smooth muscle are terminated by no less than five distinct mechanisms: 1) Diffusion into the surrounding cytosol, 2) extrusion via the $\mathrm{Na}^{+} / \mathrm{Ca}^{2+}$ exchanger, 3) extrusion via the plasma membrane $\mathrm{Ca}^{2+}$-ATPase, 4) sequestration via the sarcoplasmic reticular $\mathrm{Ca}^{2+}$-ATPase (SERCA), and 5) sequestration and redistribution via mitochondria. Detailed discussion of these important mechanisms in regulating $\mathrm{Ca}^{2+}$ signaling in vascular smooth muscle is beyond the scope of this review. However, these mechanisms clearly influence the vascular smooth muscle $\mathrm{Ca}^{2+}$ dynamics. For example, mitochondria are known to be important modulators of $\mathrm{IP}_{3}$-dependent $\mathrm{Ca}^{2+}$ signaling (37), the $\mathrm{Na}^{+} / \mathrm{Ca}^{2+}$ exchanger regulates L-type $\mathrm{Ca}^{2+}$ channel function (68), and sarcoplasmic 
reticular $\mathrm{Ca}^{2+}$-ATPase function influences ryanodine receptor-dependent $\mathrm{Ca}^{2+}$ sparks (13, 61).

Three major areas of future research are necessary to further our understanding of $\mathrm{Ca}^{2+}$ dynamics in vascular smooth muscle. First, cryptic $\mathrm{Ca}^{2+}$ signals such as $\mathrm{Ca}^{2+}$ puffs (see above) need to be visualized directly. Similarly, novel, discrete $\mathrm{Ca}^{2+}$ signals associated with store operated $\mathrm{Ca}^{2+}$ entry (SOCE) are in need of identification and characterization. Second, the relationship between local $\mathrm{Ca}^{2+}$ signals (e.g., $\mathrm{Ca}^{2+}$ waves and $\mathrm{Ca}^{2+}$ sparklets) and global $\mathrm{Ca}^{2+}$ needs to be clarified. Third and finally, future investigations should explore $\mathrm{Ca}^{2+}$ dynamics with respect to mechanisms regulating intracellular and intercellular signaling in the intact vascular syncytium. Experiments along these lines are necessary not only to assess the validity of experiments performed on isolated smooth muscle cells, but also to examine the influence of other cell types (i.e., endothelial cells) on $\mathrm{Ca}^{2+}$ signaling in vascular smooth muscle. Advances in $\mathrm{Ca}^{2+}$ imaging techniques such as high-speed confocal microscopy and availability of cell-specific $\mathrm{Ca}^{2+}$ indicators are already and will continue to be critical in advancing these areas of research.

\section{Acknowledgments}

This work was supported by grants from the Pew Charitable Trusts and the Colorado State University College Research Council (to G.C.A.), and the American Heart Association-Scientist Development Grant 0735251 N and National Institute of Health 1R01HL098200 (to M.F.N.).

\section{References}

1. Amberg GC, Bonev AD, Rossow CF, Nelson MT, Santana LF. Modulation of the molecular composition of large conductance, $\mathrm{Ca}^{+}$channels in vascular smooth muscle during hypertension. $\mathrm{J}$ Clin Invest. 2003; 112:717-724. [PubMed: 12952920]

2. Amberg GC, Earley S, Glapa SA. Local regulation of arterial L-type calcium channels by reactive oxygen species. Circ Res. 2010; 107:1002-1010. [PubMed: 20798361]

3. Amberg GC, Navedo MF, Nieves-Cintron M, Molkentin JD, Santana LF. Calcium sparklets regulate local and global calcium in murine arterial smooth muscle. J Physiol. 2007; 579:187-201. [PubMed: 17158168]

4. Amberg GC, Santana LF. Downregulation of the BK channel $\beta 1$ subunit in genetic hypertension. Circ Res. 2003; 93:965-971. [PubMed: 14551242]

5. Bayguinov O, Hagen B, Bonev AD, Nelson MT, Sanders KM. Intracellular calcium events activated by ATP in murine colonic myocytes. Am J Physiol Cell Physiol. 2000; 279:C126-135. [PubMed: 10898724]

6. Benham CD, Bolton TB. Spontaneous transient outward currents in single visceral and vascular smooth muscle cells of the rabbit. J Physiol. 1986; 381:385-406. [PubMed: 2442353]

7. Boittin FX, Macrez N, Halet G, Mironneau J. Norepinephrine-induced $\mathrm{Ca}^{2+}$ waves depend on $\mathrm{InsP}_{3}$ and ryanodine receptor activation in vascular myocytes. Am J Physiol. 1999; 277:C139-151. [PubMed: 10409117]

8. Bonev AD, Jaggar JH, Rubart M, Nelson MT. Activators of protein kinase C decrease $\mathrm{Ca}^{2+}$ spark frequency in smooth muscle cells from cerebral arteries. Am J Physiol. 1997; 273:C2090-2095. [PubMed: 9435516]

9. Bootman MD, Berridge MJ. Subcellular $\mathrm{Ca}^{2+}$ signals underlying waves and graded responses in HeLa cells. Curr Biol. 1996; 6:855-865. [PubMed: 8805305]

10. Brenner R, Perez GJ, Bonev AD, Eckman DM, Kosek JC, Wiler SW, Patterson AJ, Nelson MT, Aldrich RW. Vasoregulation by the b1 subunit of the calcium-activated potassium channel. Nature. 2000; 407:870-876. [PubMed: 11057658]

11. Chaplin NL, Amberg GC. Hydrogen peroxide mediates oxidant-dependent stimulation of arterial smooth muscle L-type calcium channels. Am J Physiol Cell Physiol. 2012; 302:C1382-1393. [PubMed: 22322977] 
12. Cheng H, Lederer WJ, Cannell MB. Calcium sparks: elementary events underlying excitationcontraction coupling in heart muscle. Science. 1993; 262:740-744. [PubMed: 8235594]

13. Cheranov SY, Jaggar JH. Sarcoplasmic reticulum calcium load regulates rat arterial smooth muscle calcium sparks and transient $\mathrm{K}_{\mathrm{Ca}}$ currents. J Physiol. 2002; 544:71-84. [PubMed: 12356881]

14. Devine CE, Somlyo AV, Somlyo AP. Sarcoplasmic reticulum and excitation-contraction coupling in mammalian smooth muscles. J Cell Biol. 1972; 52:690-718. [PubMed: 5061887]

15. Dixon RE, Yuan C, Cheng EP, Navedo MF, Santana LF. $\mathrm{Ca}^{2+}$ signaling amplification by oligomerization of L-type Cav1.2 channels. Proc Natl Acad Sci U S A. 2012; 109:1749-1754. [PubMed: 22307641]

16. Evans RJ, Lewis C, Virginio C, Lundstrom K, Buell G, Surprenant A, North RA. Ionic permeability of, and divalent cation effects on, two ATP-gated cation channels (P2X receptors) expressed in mammalian cells. J Physiol. 1996; 497 ( Pt 2):413-422. [PubMed: 8961184]

17. Gonzales AL, Amberg GC, Earley S. $\mathrm{Ca}^{2+}$ release from the sarcoplasmic reticulum is required for sustained TRPM4 activity in cerebral artery smooth muscle cells. Am J Physiol Cell Physiol. 2010; 299:C279-288. [PubMed: 20427713]

18. Gonzales AL, Earley S. Endogenous cytosolic $\mathrm{Ca}^{2+}$ buffering is necessary for TRPM4 activity in cerebral artery smooth muscle cells. Cell calcium. 2012; 51:82-93. [PubMed: 22153976]

19. Gonzales AL, Garcia ZI, Amberg GC, Earley S. Pharmacological inhibition of TRPM4 hyperpolarizes vascular smooth muscle. American journal of physiology Cell physiology. 2010; 299:C1195-1202. [PubMed: 20826763]

20. Gordienko DV, Bolton TB. Crosstalk between ryanodine receptors and $\mathrm{IP}_{3}$ receptors as a factor shaping spontaneous $\mathrm{Ca}^{2+}$-release events in rabbit portal vein myocytes. J Physiol. 2002; 542:743-762. [PubMed: 12154176]

21. Hill-Eubanks DC, Werner ME, Heppner TJ, Nelson MT. Calcium signaling in smooth muscle. Cold Spring Harb Perspect Biol. 2011; 3:a004549. [PubMed: 21709182]

22. Hille, B. Ion channels of excitable membranes. 3. Suderland, Massachusetts: Sinauer Associates, Inc; 2001.

23. Iino M, Kasai H, Yamazawa T. Visualization of neural control of intracellular $\mathrm{Ca}^{2+}$ concentration in single vascular smooth muscle cells in situ. EMBO J. 1994; 13:5026-5031. [PubMed: 7957068]

24. Inscho EW, Cook AK, Imig JD, Vial C, Evans RJ. Physiological role for $\mathrm{P}_{2} \mathrm{X}_{1}$ receptors in renal microvascular autoregulatory behavior. J Clin Invest. 2003; 112:1895-1905. [PubMed: 14679185]

25. Jaggar JH. Intravascular pressure regulates local and global $\mathrm{Ca}^{2+}$ signaling in cerebral artery smooth muscle cells. Am J Physiol Cell Physiol. 2001; 281:C439-448. [PubMed: 11443043]

26. Jaggar JH, Nelson MT. Differential regulation of $\mathrm{Ca}^{2+}$ sparks and $\mathrm{Ca}^{2+}$ waves by UTP in rat cerebral artery smooth muscle cells. Am J Physiol Cell Physiol. 2000; 279:C1528-1539. [PubMed: 11029300]

27. Jaggar JH, Porter VA, Lederer WJ, Nelson MT. Calcium sparks in smooth muscle. Am J Physiol Cell Physiol. 2000; 278:C235-256. [PubMed: 10666018]

28. Jaggar JH, Wellman GC, Heppner TJ, Porter VA, Perez GJ, Gollasch M, Kleppisch T, Rubart M, Stevenson AS, Lederer WJ, Knot HJ, Bonev AD, Nelson MT. $\mathrm{Ca}^{2+}$ channels, ryanodine receptors and $\mathrm{Ca}^{2+}$-activated $\mathrm{K}^{+}$channels: a functional unit for regulating arterial tone. Acta Physiol Scand. 1998; 164:577-587. [PubMed: 9887980]

29. Knot HJ, Nelson MT. Regulation of arterial diameter and wall $\left[\mathrm{Ca}^{2+}\right]$ in cerebral arteries of rat by membrane potential and intravascular pressure. J Physiol. 1998; 508 (Pt 1):199-209. [PubMed: 9490839]

30. Knot HJ, Standen NB, Nelson MT. Ryanodine receptors regulate arterial diameter and wall $\left[\mathrm{Ca}^{2+}\right]$ in cerebral arteries of rat via $\mathrm{Ca}^{2+}$-dependent $\mathrm{K}^{+}$channels. J Physiol. 1998; 508 ( Pt 1):211-221. [PubMed: 9490841]

31. Lamont $\mathrm{C}$, Vainorius E, Wier WG. Purinergic and adrenergic $\mathrm{Ca}^{2+}$ transients during neurogenic contractions of rat mesenteric small arteries. J Physiol. 2003; 549:801-808. [PubMed: 12740429]

32. Lamont C, Vial C, Evans RJ, Wier WG. P2X1 receptors mediate sympathetic postjunctional $\mathrm{Ca}^{2+}$ transients in mesenteric small arteries. Am J Physiol Heart Circ Physiol. 2006; 291:H3106-3113. [PubMed: 16920810] 
33. Lamont C, Wier WG. Different roles of ryanodine receptors and inositol (1,4,5)-trisphosphate receptors in adrenergically stimulated contractions of small arteries. Am J Physiol Heart Circ Physiol. 2004; 287:H617-625. [PubMed: 15072954]

34. Lamont C, Wier WG. Evoked and spontaneous purinergic junctional $\mathrm{Ca}^{2+}$ transients $(\mathrm{jCaTs})$ in rat small arteries. Circ Res. 2002; 91:454-456. [PubMed: 12242262]

35. Lewis CJ, Ennion SJ, Evans RJ. P2 purinoceptor-mediated control of rat cerebral (pial) microvasculature; contribution of P2X and P2Y receptors. J Physiol. 2000; 527(Pt 2):315-324. [PubMed: 10970432]

36. Mauban JR, Zacharia J, Zhang J, Wier WG. Vascular tone and $\mathrm{Ca}^{2+}$ signaling in murine cremaster muscle arterioles in vivo. Microcirculation. 2012

37. McCarron JG, Olson ML, Chalmers S. Mitochondrial regulation of cytosolic $\mathrm{Ca}^{2+}$ signals in smooth muscle. Pflugers Arch. 2012; 464:51-62. [PubMed: 22555917]

38. Miriel VA, Mauban JR, Blaustein MP, Wier WG. Local and cellular $\mathrm{Ca}^{2+}$ transients in smooth muscle of pressurized rat resistance arteries during myogenic and agonist stimulation. J Physiol. 1999; 518 ( Pt 3):815-824. [PubMed: 10420017]

39. Moosmang S, Schulla V, Welling A, Feil R, Feil S, Wegener JW, Hofmann F, Klugbauer N. Dominant role of smooth muscle L-type calcium channel $\mathrm{Ca}_{\mathrm{V}} 1.2$ for blood pressure regulation. EMBO J. 2003; 22:6027-6034. [PubMed: 14609949]

40. Navedo MF, Amberg GC, Nieves M, Molkentin JD, Santana LF. Mechanisms underlying heterogeneous $\mathrm{Ca}^{2+}$ sparklet activity in arterial smooth muscle. J Gen Physiol. 2006; 127:611622. [PubMed: 16702354]

41. Navedo MF, Amberg GC, Votaw VS, Santana LF. Constitutively active L-type $\mathrm{Ca}^{2+}$ channels. Proc Natl Acad Sci U S A. 2005; 102:11112-11117. [PubMed: 16040810]

42. Navedo MF, Amberg GC, Westenbroek RE, Sinnegger-Brauns MJ, Catterall WA, Striessnig J, Santana LF. Cav1.3 channels produce persistent calcium sparklets, but Cav1.2 channels are responsible for sparklets in mouse arterial smooth muscle. Am J Physiol Heart Circ Physiol. 2007; 293:H1359-1370. [PubMed: 17526649]

43. Navedo MF, Cheng EP, Yuan C, Votaw S, Molkentin JD, Scott JD, Santana LF. Increased coupled gating of L-type $\mathrm{Ca}^{2+}$ channels during hypertension and Timothy syndrome. Circ Res. 2010; 106:748-756. [PubMed: 20110531]

44. Navedo MF, Nieves-Cintron M, Amberg GC, Yuan C, Votaw VS, Lederer WJ, McKnight GS, Santana LF. AKAP150 is required for stuttering persistent $\mathrm{Ca}^{2+}$ sparklets and angiotensin IIinduced hypertension. Circ Res. 2008; 102:e1-e11. [PubMed: 18174462]

45. Navedo MF, Takeda Y, Nieves-Cintron M, Molkentin JD, Santana LF. Elevated $\mathrm{Ca}^{2+}$ sparklet $^{2}$ activity during acute hyperglycemia and diabetes in cerebral arterial smooth muscle cells. Am J Physiol Cell Physiol. 2010; 298:C211-220. [PubMed: 19846755]

46. Nelson MT, Cheng H, Rubart M, Santana LF, Bonev AD, Knot HJ, Lederer WJ. Relaxation of arterial smooth muscle by calcium sparks. Science. 1995; 270:633-637. [PubMed: 7570021]

47. Nieves-Cintron M, Amberg GC, Navedo MF, Molkentin JD, Santana LF. The control of $\mathrm{Ca}^{2+}$ influx and NFATc3 signaling in arterial smooth muscle during hypertension. Proc Natl Acad Sci U S A. 2008; 105:15623-15628. [PubMed: 18832165]

48. Perez GJ, Bonev AD, Nelson MT. Micromolar $\mathrm{Ca}^{2+}$ from sparks activates $\mathrm{Ca}^{2+}$-sensitive $\mathrm{K}^{+}$ channels in rat cerebral artery smooth muscle. Am J Physiol Cell Physiol. 2001; 281:C1769-1775. [PubMed: 11698234]

49. Porter VA, Bonev AD, Knot HJ, Heppner TJ, Stevenson AS, Kleppisch T, Lederer WJ, Nelson MT. Frequency modulation of $\mathrm{Ca}^{2+}$ sparks is involved in regulation of arterial diameter by cyclic nucleotides. Am J Physiol. 1998; 274:C1346-1355. [PubMed: 9612222]

50. Rubart M, Patlak JB, Nelson MT. $\mathrm{Ca}^{2+}$ currents in cerebral artery smooth muscle cells of rat at physiological $\mathrm{Ca}^{2+}$ concentrations. J Gen Physiol. 1996; 107:459-472. [PubMed: 8722560]

51. Saleh SN, Greenwood IA. Activation of chloride currents in murine portal vein smooth muscle cells by membrane depolarization involves intracellular calcium release. Am J Physiol Cell Physiol. 2005; 288:C122-131. [PubMed: 15355851]

52. Santana LF, Navedo MF. Molecular and biophysical mechanisms of $\mathrm{Ca}^{2+}$ sparklets in smooth muscle. J Mol Cell Cardiol. 2009; 47:436-444. [PubMed: 19616004] 
53. Santana LF, Navedo MF. Natural inequalities: why some L-type $\mathrm{Ca}^{2+}$ channels work harder than others. The Journal of general physiology. 2010; 136:143-147. [PubMed: 20660657]

54. Schubert R, Nelson MT. Protein kinases: tuners of the $\mathrm{BK}_{\mathrm{Ca}}$ channel in smooth muscle. Trends Pharmacol Sci. 2001; 22:505-512. [PubMed: 11583807]

55. Sonkusare SK, Bonev AD, Ledoux J, Liedtke W, Kotlikoff MI, Heppner TJ, Hill-Eubanks DC, Nelson MT. Elementary $\mathrm{Ca}^{2+}$ signals through endothelial TRPV4 channels regulate vascular function. Science. 2012; 336:597-601. [PubMed: 22556255]

56. Stewart M, Needham M, Bankhead P, Gardiner TA, Scholfield CN, Curtis TM, McGeown JG. Feedback via $\mathrm{Ca}^{2+}$-activated ion channels modulates endothelin 1 signaling in retinal arteriolar smooth muscle. Invest Ophthalmol Vis Sci. 2012; 53:3059-3066. [PubMed: 22427579]

57. Takeda Y, Nystoriak MA, Nieves-Cintron M, Santana LF, Navedo MF. Relationship between $\mathrm{Ca}^{2+}$ sparklets and sarcoplasmic reticulum $\mathrm{Ca}^{2+}$ load and release in rat cerebral arterial smooth muscle. Am J Physiol Heart Circ Physiol. 2011; 301:H2285-2294. [PubMed: 21984539]

58. Tovey SC, de Smet P, Lipp P, Thomas D, Young KW, Missiaen L, De Smedt H, Parys JB, Berridge MJ, Thuring J, Holmes A, Bootman MD. Calcium puffs are generic $\mathrm{InsP}_{3}$-activated elementary calcium signals and are downregulated by prolonged hormonal stimulation to inhibit cellular calcium responses. Journal of cell science. 2001; 114:3979-3989. [PubMed: 11739630]

59. Wang Q, Hogg RC, Large WA. Properties of spontaneous inward currents recorded in smooth muscle cells isolated from the rabbit portal vein. J Physiol. 1992; 451:525-537. [PubMed: 1403823]

60. Wang SQ, Song LS, Lakatta EG, Cheng H. $\mathrm{Ca}^{2+}$ signalling between single L-type $\mathrm{Ca}^{2+}$ channels and ryanodine receptors in heart cells. Nature. 2001; 410:592-596. [PubMed: 11279498]

61. Wellman GC, Santana LF, Bonev AD, Nelson MT. Role of phospholamban in the modulation of arterial $\mathrm{Ca}^{2+}$ sparks and $\mathrm{Ca}^{2+}$-activated $\mathrm{K}^{+}$channels by cAMP. Am J Physiol Cell Physiol. 2001; 281:C1029-1037. [PubMed: 11502581]

62. Westcott EB, Goodwin EL, Segal SS, Jackson WF. Function and expression of ryanodine receptors and inositol 1,4,5-trisphosphate receptors in smooth muscle cells of murine feed arteries and arterioles. J Physiol. 2012; 590:1849-1869. [PubMed: 22331418]

63. Wier WG, Zang WJ, Lamont C, Raina H. Sympathetic neurogenic $\mathrm{Ca}^{2+}$ signalling in rat arteries: ATP, noradrenaline and neuropeptide Y. Exp Physiol. 2009; 94:31-37. [PubMed: 18931047]

64. Wray S, Burdyga T. Sarcoplasmic reticulum function in smooth muscle. Physiological reviews. 2010; 90:113-178. [PubMed: 20086075]

65. Zacharia J, Zhang J, Wier WG. $\mathrm{Ca}^{2+}$ signaling in mouse mesenteric small arteries: myogenic tone and adrenergic vasoconstriction. Am J Physiol Heart Circ Physiol. 2007; 292:H1523-1532. [PubMed: 17114244]

66. Zang WJ, Balke CW, Wier WG. Graded $a_{1}$-adrenoceptor activation of arteries involves recruitment of smooth muscle cells to produce 'all or none' $\mathrm{Ca}^{2+}$ signals. Cell calcium. 2001; 29:327-334. [PubMed: 11292389]

67. Zang WJ, Zacharia J, Lamont C, Wier WG. Sympathetically evoked $\mathrm{Ca}^{2+}$ signaling in arterial smooth muscle. Acta Pharmacol Sin. 2006; 27:1515-1525. [PubMed: 17112404]

68. Zhang J, Ren C, Chen L, Navedo MF, Antos LK, Kinsey SP, Iwamoto T, Philipson KD, Kotlikoff MI, Santana LF, Wier WG, Matteson DR, Blaustein MP. Knockout of $\mathrm{Na}^{+} / \mathrm{Ca}^{2+}$ exchanger in smooth muscle attenuates vasoconstriction and L-type $\mathrm{Ca}^{2+}$ channel current and lowers blood pressure. Am J Physiol Heart Circ Physiol. 2010; 298:H1472-1483. [PubMed: 20173044] 


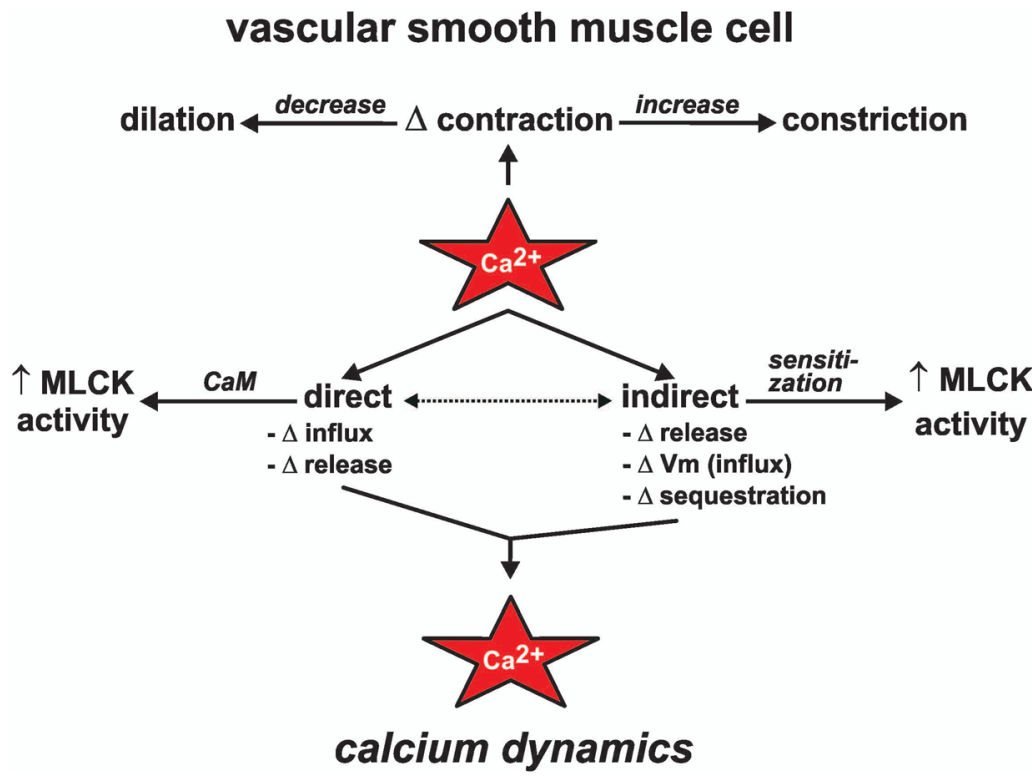

Figure 1. Overview of calcium dynamics in vascular smooth muscle $\mathrm{Ca}^{2+}$ influences the state of vascular smooth muscle contraction directly and indirectly. Direct mechanisms include changes $(\Delta)$ in $\mathrm{Ca}^{2+}$ influx and release from intracellular $\mathrm{Ca}^{2+}$ stores leading to increased $\mathrm{Ca}^{2+}$ within the cell, binding of $\mathrm{Ca}^{2+}$ to calmodulin $(\mathrm{CaM})$, and activation of myosin light chain kinase (MLCK). Indirect mechanisms include changes in $\mathrm{Ca}^{2+}$ influx via alterations in plasma membrane potential $(\mathrm{Vm}), \mathrm{Ca}^{2+}$ release from intracellular stores, $\mathrm{Ca}^{2+}$ sequestration, and $\mathrm{Ca}^{2+}$ sensitization of the contractile apparatus. 


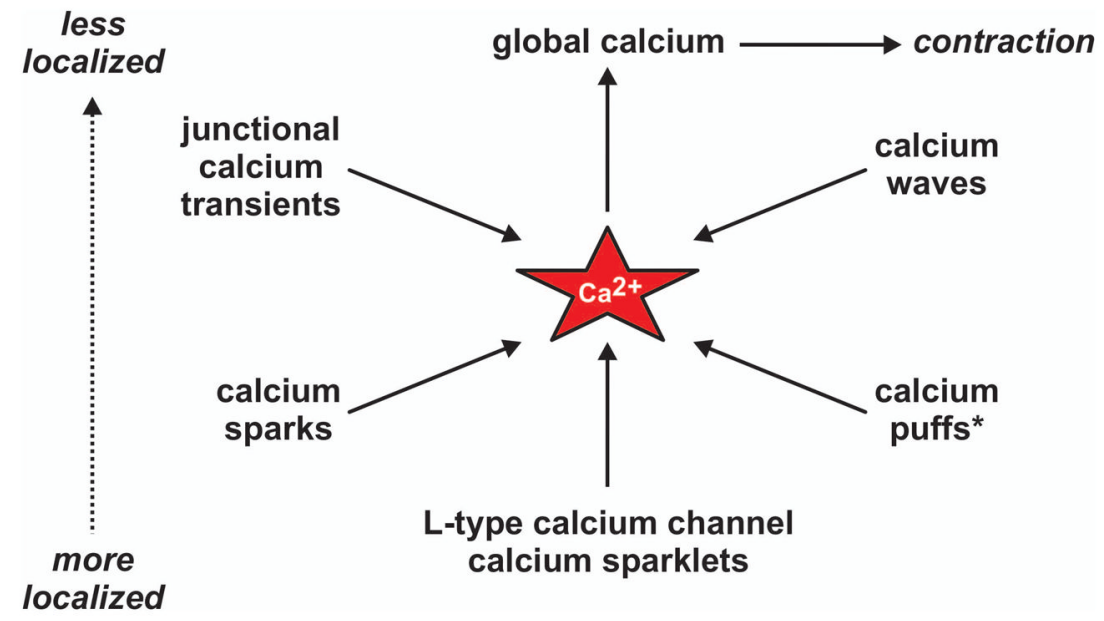

Figure 2. Overview of calcium signaling events in vascular smooth muscle Discrete subcellular $\mathrm{Ca}^{2+}$ signaling events (junctional $\mathrm{Ca}^{2+}$ transients, $\mathrm{Ca}^{2+}$ waves, $\mathrm{Ca}^{2+}$ sparks, $\mathrm{Ca}^{2+}$ puffs, and $\mathrm{Ca}^{2+}$ sparklets) can be classified as either more or less localized with respect to total cell volume. * Direct visualization of $\mathrm{Ca}^{2+}$ puffs in arterial smooth muscle is lacking; however, abundant indirect evidence supports their existence. 


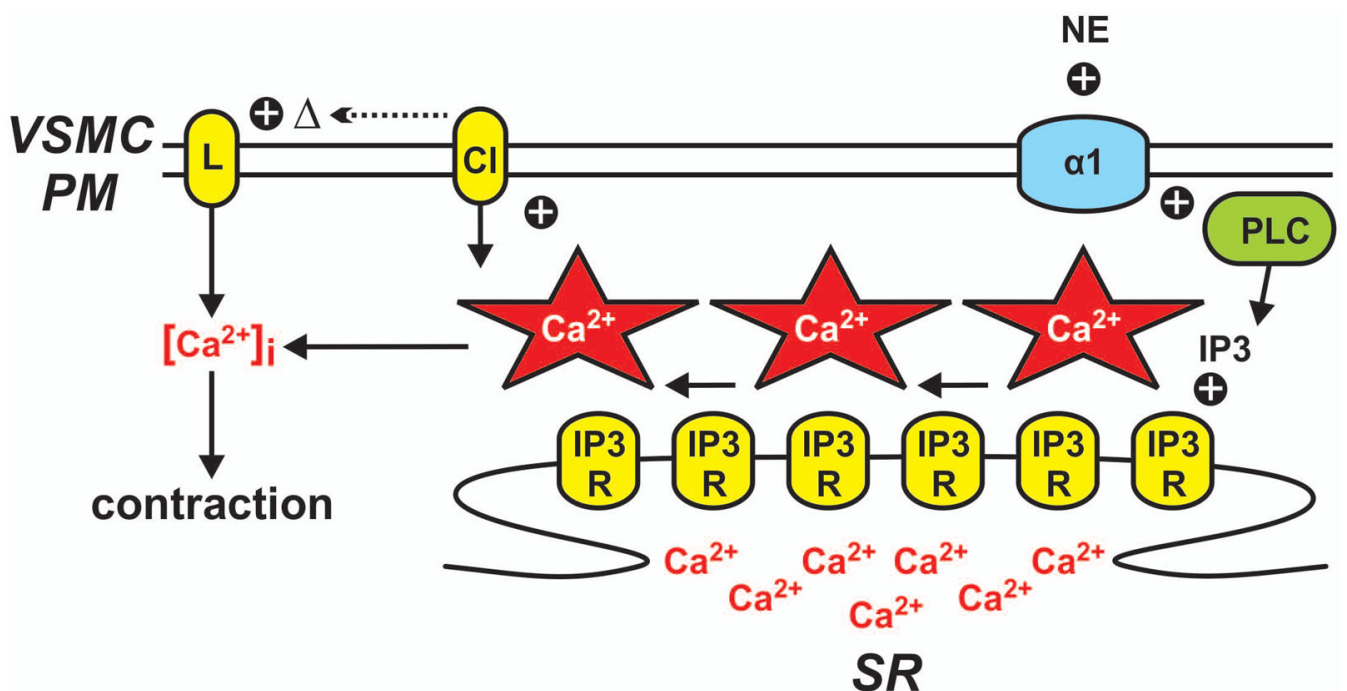

Figure 3. Vascular smooth muscle calcium waves

Norepinephrine (NE)-dependent stimulation of $a_{1}$ adrenergic receptors $(a 1 R)$ on the vascular smooth muscle cell plasma membrane (VSMC PM) leads to activation of phospholipase C (PLC) and the production of inositol 1,4,5-trisphosphate (IP3). IP3 in turn promotes the opening of IP3 receptors (IP3R) on the sarcoplasmic reticulum (SR) resulting in a propagating series of $\mathrm{Ca}^{2+}$ release events (i.e., a $\mathrm{Ca}^{2+}$ wave). $\mathrm{Ca}^{2+}$ waves increase contraction directly by elevating global intracellular $\mathrm{Ca}^{2+}\left(\left[\mathrm{Ca}^{2+}\right]_{\mathrm{i}}\right) . \mathrm{Ca}^{2+}$ waves also modulate contraction indirectly by altering plasma membrane potential (and thus voltagedependent $\mathrm{Ca}^{2+}$ influx through Cav1.2 L-type $\mathrm{Ca}^{2+}$ channels) by stimulating plasmalemmal $\mathrm{Ca}^{2+}$-activated chloride channels. 


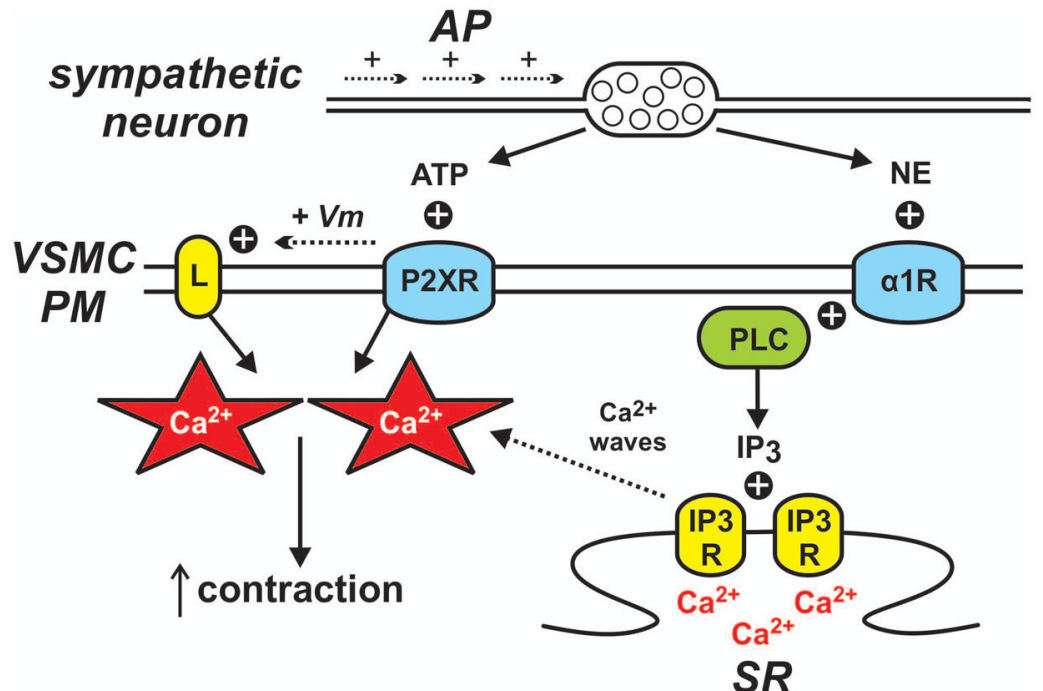

Figure 4. Vascular smooth muscle junctional calcium transients

Neuronal action potentials (AP) promote the release of ATP and norepinephrine (NE) from perivascular nerve terminals. Norepinephrine stimulates $a_{1}$ adrenergic receptors $(a 1 R)$ giving rise to $\mathrm{Ca}^{2+}$ waves as described in Figure 3 while ATP opens $\mathrm{Ca}^{2+}$-permeable purinergic receptors $(\mathrm{P} 2 \mathrm{XR})$ on the vascular smooth muscle cell plasma membrane (VSMC $\mathrm{PM})$ producing localized junctional $\mathrm{Ca}^{2+}$ transients. Purinergic receptor activation also leads to plasma membrane depolarization $(+\mathrm{Vm})$ and increased opening of voltage-dependent Cav1.2 L-type $\mathrm{Ca}^{2+}$ channels (L). $\mathrm{Ca}^{2+}$ influx from junctional $\mathrm{Ca}^{2+}$ transients and L-type $\mathrm{Ca}^{2+}$ channels summate to increase contraction. 


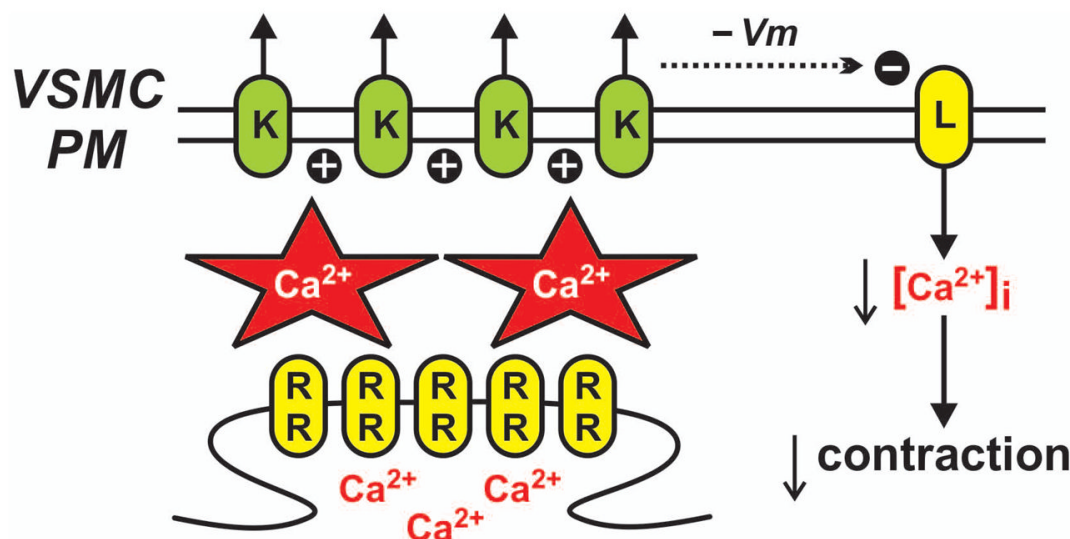

$S R$

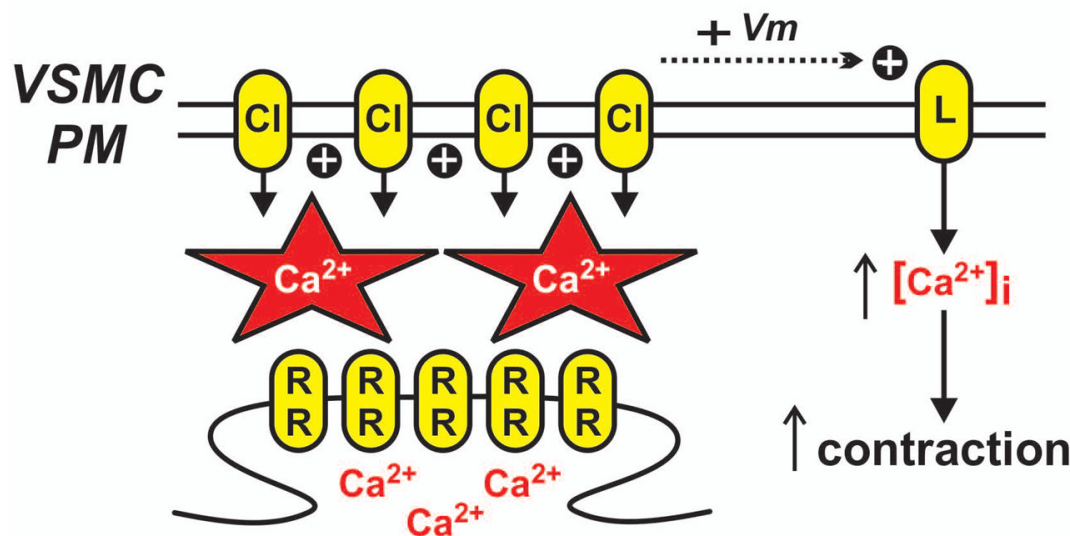

SR

Figure 5. Vascular smooth muscle calcium sparks

$\mathrm{Ca}^{2+}$-permeable ryanodine receptors $(\mathrm{RR})$ on the sarcoplasmic reticulum (SR) produce highly localized sites of elevated $\mathrm{Ca}^{2+}$ (i.e., $\mathrm{Ca}^{2+}$ sparks). $\mathrm{Ca}^{2+}$ sparks near the vascular smooth muscle cell plasma membrane (VSMC PM) increase the activity of plasmalemmal ion channels including $\mathrm{Ca}^{2+}$ activated $\mathrm{K}^{+}(\mathrm{K})$ and $\mathrm{Ca}^{2+}$-activated $\mathrm{Cl}^{-}(\mathrm{Cl})$ channels. $\mathrm{Ca}^{2+}$ spark-dependent activation of $\mathrm{K}^{+}$channels generates hyperpolarizing outward currents (via $\mathrm{K}^{+}$efflux) resulting in decreased opening of voltage-dependent Cav1.2 L-type $\mathrm{Ca}^{2+}$ channels (L) and decreased contraction. Conversely, $\mathrm{Ca}^{2+}$ spark-dependent activation of $\mathrm{Cl}^{-}$ channels generates depolarizing $(+\mathrm{Vm})$ inward currents (via $\mathrm{Cl}^{-}$efflux) resulting in increased opening of L-type $\mathrm{Ca}^{2+}$ channels and increased contraction. 


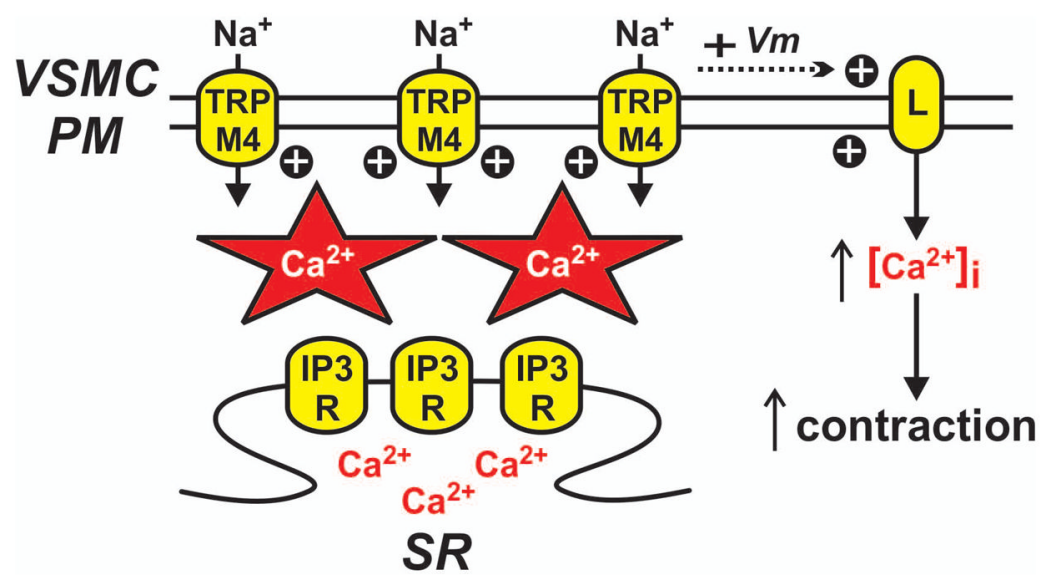

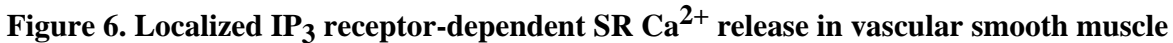
$\mathrm{Ca}^{2+}$-permeable inositol 1,4,5-trisphosphate receptors (IP3R) on the sarcoplasmic reticulum (SR) can produce non-propagating localized sites of elevated $\mathrm{Ca}^{2+} \cdot \mathrm{IP}_{3}$ receptor $\mathrm{Ca}^{2+}$ release events near the vascular smooth muscle cell plasma membrane (VSMC PM) increase the activity of plasmalemmal ion channels such as transient receptor potential melastatin 4 (TRPM4). $\mathrm{Ca}^{2+}$ puff-dependent activation of TRPM4 channels generates depolarizing (+ $\mathrm{Vm}$ ) inward currents (via $\mathrm{Na}^{+}$influx) resulting in increased opening of voltage-dependent Cav1.2 L-type $\mathrm{Ca}^{2+}$ channels (L) and increased contraction. 


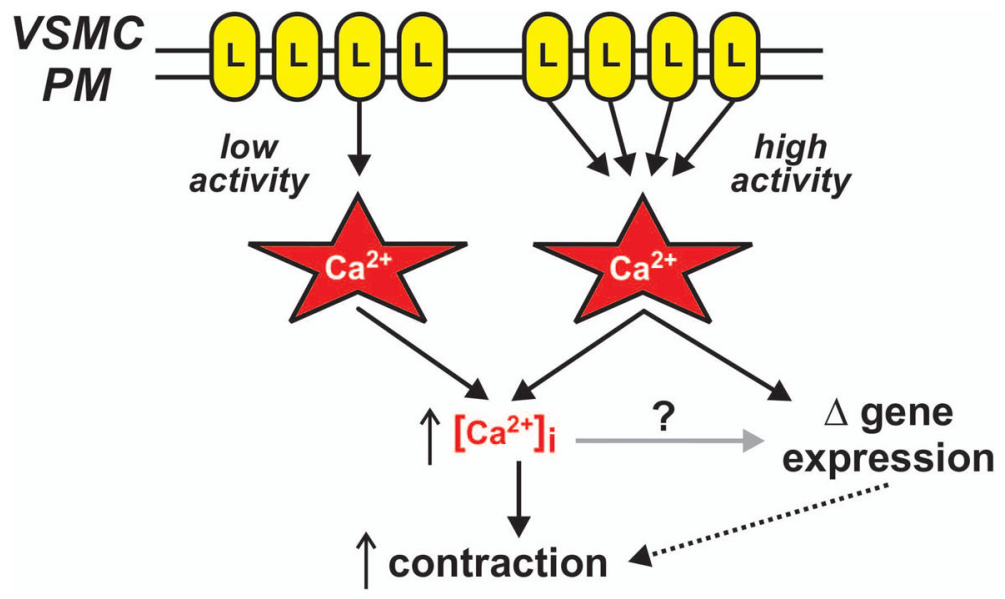

Figure 7. Vascular smooth muscle L-type calcium channel calcium sparklets Cav1.2 L-type $\mathrm{Ca}^{2+}$ channels (L) in the vascular smooth muscle cell plasma membrane (VSMC PM) produce highly localized $\mathrm{Ca}^{2+}$ influx events (i.e., $\mathrm{Ca}^{2+}$ sparklets). Brief stochastic opening of single L-type $\mathrm{Ca}^{2+}$ channels produce low activity $\mathrm{Ca}^{2+}$ sparklet sites while prolonged opening of one or more clustered L-type $\mathrm{Ca}^{2+}$ channels produce high activity $\mathrm{Ca}^{2+}$ sparklet sites. $\mathrm{Ca}^{2+}$ influx from low and high activity $\mathrm{Ca}^{2+}$ sparklet sites contribute to global intracellular $\mathrm{Ca}^{2+}\left(\left[\mathrm{Ca}^{2+}\right]_{\mathrm{i}}\right)$ resulting in contraction. Elevated $\mathrm{Ca}^{2+}$ concentrations at high activity $\mathrm{Ca}^{2+}$ sparklet sites (and perhaps global intracellular $\mathrm{Ca}^{2+}$ as well) contribute to changes in gene expression associated with increased contraction. 


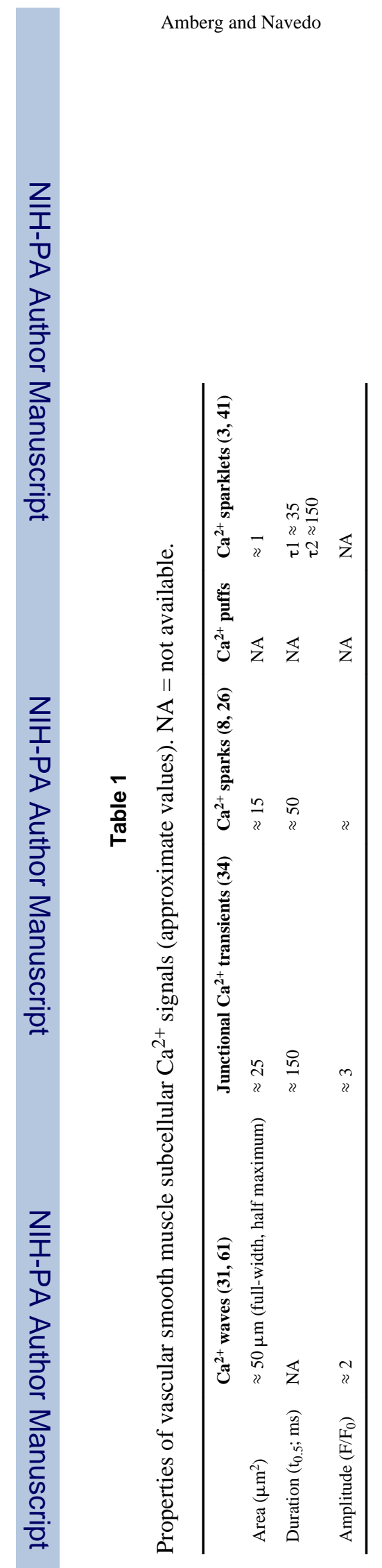

Microcirculation. Author manuscript; available in PMC 2014 May 01. 